\title{
Microfinance Institutions in Kosovo Regulation and Supervision Issues and Challenges
}

\author{
Veton Zeqiraj ${ }^{1,2}$, Fitor Murati ${ }^{1} \&$ Valon Zeqiraj $^{1}$ \\ ${ }^{1}$ Faculty of Economics, University of Prishtine, Agim Ramadani, Kosovo \\ ${ }^{2}$ Central Bank of the Republic of Kosovo Garibaldi, Prishtinë, Kosovo \\ Correspondence: Veton Zeqiraj, Faculty of Economics, University of Prishtine, Agim Ramadani, Kosovo; \\ Central Bank of the Republic of Kosovo Garibaldi, Prishtinë, Kosovo. E-mail: veton.zeqiraj@bqk-kos.org
}

Received: January 23, 2017

Accepted: February 10, 2017

Online Published: November 13, 2017

doi:10.5539/res.v9n4p94

URL: http://doi.org/10.5539/res.v9n4p94

\begin{abstract}
We examine the need for regulatory reform of Microfinance Institutions (MFIs) in Kosovo. On its substance, this paper highlights the prevailing importance of a regulatory reform that enables transformation of MFIs incorporated as Non-Governmental Organizations (NGOs) to Joint Stock Companies (JSC) and the respective implications. In doing so, the paper highlights a wide range of challenging issues related to the regulation and supervision of MFIs with careful reflections carried out and strategic decisions considered. Intrinsic and extrinsic challenging issues are investigated in the context of local market settings and circumstances with a great deal of consideration of international standards and best practices on regulation and supervision of MFIs.
\end{abstract}

Keywords: microfinance, NGO, regulation, supervision, transformation

\section{Introduction}

Micro Finance Institutions have played a very important role in Kosovo, especially during the first years of UNMIK (Note 1) administration, when financial activities as well as financial services providers were quite limited in practice due to the prevailing extraordinary circumstances. Given this fact, it cannot be a surprise that MFIs were incorporated as local Non-Governmental Organizations (NGOs), mostly using funds from foreign donors, as the most and even almost only practical way at that time to enable financial services being provided, even if to a limited extent and with certain significant weaknesses, which are almost inevitably associated by nature to this model, especially in what it refers to the corporate governance and control of these institutions.

Fortunately, these transitional and certainly difficult times are practically over and now there is a regular financial system in place where banks can develop their financial activities in an ordinary way. Closely related to it, it must be said that it is estimated that many MFIs will not continue to receive funds or grants from donors in the future, posing so a serious question mark on the feasibility of their presence in Kosovo in the next years. On the other hand, it must also be said, so as to be able to see the full picture, that MFIs still play a significant role in what it refers to certain relatively remote areas of Kosovo and customers that do not have an easy access to ordinary banking services.

Accordingly, from the regulatory perspective, it should be considered what should be the future role of MFIs in the context of a stable and integrated financial system, as well as considering to what extent this kind of institutions should be regulated and supervised, including who should do it.

\subsection{Relevance and Implications}

Microfinance sector plays an important role in the effectiveness of the economy. Relative to non-financial businesses, the failure of a MFI can have a greater impact on stakeholders who, in most of the cases, have placed a substantial portion of their funds and investments. There are a number of factors that set MFIs apart from other business firms and results in their being subject to regulation and supervision;

1) In all economies, banks provide a critical source of funding, whereas MFIs "focus on providing credit to the poor who have no access to commercial banks, in order to reduce poverty and to help the poor with setting up their own income generating businesses" (Hermes, Lensink, \& Meesters, 2011). 
2) MFIs are funded from different investors, including institutional investors, therefore have a duty to do all they can to preserve their investment value.

3) Self-supervision and quasi regulation has virtually never been effective. Discussions about regulating MFIs according to Christen and Rosenberg (Christen \& Rosenberg, 2003) are "often motivated by different objectives".

4) Looser regulation combined with human greed plays a key role in financial mess, allowing therefore room for MFIs to perform mixed activities, mainly as a consequence of its general purpose of social and economic development and its incorporation as NGOs.

5) Micro finance is about building permanent local financial institutions and a powerful instrument against poverty (CGAP, 2004).

\subsection{Aims and Objectives}

The aim of the paper is to conduct a research study on regulation and supervision of MFIs in Kosovo (one of the authors (Note 2) of the research being adviser of Risk Management Unit in CBK). Outcome of the research are intended to provide valuable information to the Association of Microfinance Institutions of Kosovo (AMIK) and Central Bank of the Republic of Kosovo (CBK) for their advisory, regulatory and supervisory capacity in order to enhance the regulatory and supervisory framework.

The research is organized to tackle this important issue through the following objectives;

1) Explore foundations of effective regulation and supervision of MFIs. Examine theories and international practices on regulation and supervision of MFI's,

2) Conduct a review of regulation and supervision of MFIs in Kosovo. Review key regulatory challenges and supervisory issues, through discussion with executives, regulators and auditors.

\section{Literature, Theory, Standards and Practices}

Microcredit and microfinance are relatively new terms in the field of development, first coming to prominence in the 1970s (Robinson, 2001; Otero, 1999). Prior to microcredit and microfinance (1950 to 1970), the provision of financial services by donors or governments was mainly in the form of subsidised rural credit programmes. Such practices repeatedly resulted in high loan defaults, loses and failure to reach poor rural households (Robinson, 2001).

Microfinance was highlighted on the public agenda after the UN Year of Microcredit in 2005 and the awarding of the Nobel Peace Prize to Mohammad Yunus and the Grameen Bank in 2006 (Mersland \& Strøm, 2008). According to the World Bank definition, the term microfinance refers to "provision of financial services" (savings and credit) to "the poor". The European Microfinance Network report that, "microfinance offers people excluded from the formal financial services the opportunity to obtain microloans in order to generate income and engage in productive activities, often by expanding their small businesses" (The European Microfinance Network, 2016).

As an economic development approach, "microfinance has evolved to benefit the low-income part of a given society" (Dahir, 2015). Nevertheless, microfinance as a product is offered by various types of institutions, mainly Credit Unions, Commercial Banks and MFI NGOs, the last being typical microfinance providers in Kosovo.

Financial institutions, that qualify as such based on the national law of the country that they operate, especially those that collect deposits, are typically subject to licensing, supervision and regulation by the respective regulatory authorities. On the other hand, "in most countries $85 \%$ of MFIs are not financial intermediaries-i.e., they are lenders only, and do not take deposits from the public. There is probably no strong reason for public prudential oversight of such MFIs, since protection of depositors is usually viewed as the principal rationale for such oversight" (The Consultative Group to Assist the Poor-CGAP, 2010). Nevertheless, not collecting deposits is not an objective criterion for deregulating MFIs; hence the issue remains to what extent and how specifically should MFIs be regulated, so as to adjust the regulatory framework to the viability of local market circumstances.

According to Christen and Rosenberg Christen and Rosenberg (2003), "regulation of microfinance is being discussed in one country after another. But the people doing the discussing are often motivated by differing objectives, which tends to confuse the dialogue". 
1) Looking to fund themselves, NGOs with microcredit operations often want to be licensed (and thus regulated) in order to access deposits from the public, or credit lines from donors or governments.

2) Donors and governments may expect that setting up a special regulatory window for microfinance will speed the emergence of sustainable MFIs.

3) Many MFIs charge surprisingly high interest rates. Government may view these rates as exploitative and want to protect small borrowers from them.

4) Local authorities are sometimes troubled by the weakness of many MFIs, and unimpressed with the coordination and supervision being exercised by the donors who fund them. They want someone to step in and clean up a situation that they think is hurting the development of microfinance in their country.

All of the above motivations come into play to large extent in Kosovo and are legitimate reasons for the interest of better regulating MFI sector. It is important to recognize, however, that legal framework reform is not a miracle cure for addressing all the problems.

Basel Committee on Banking Supervision suggests that "other deposit taking institutions (ODTIs that are not banks) should be subject to regulation and supervision commensurate to the type, complexity and size of their transactions". Similarly, Van Greuning et al. (Greuning, Gallardo, \& Randhawa, 1998) on their proposed "Framework for Regulating MFIs", report that "differences in the organizational and operating characteristics of the various types of MFIs leave them vulnerable to certain risks".

The Law on Banks, Microfinance Institutions and Non-bank Financial Institutions (Law No.04/L-093) in Kosovo, defines as financial institution "all banks, non-bank financial institutions and microfinance intuitions", whereas microfinance institution is defined as "a legal entity organized as either an NGO under the NGO Law or as a joint stock company under the Law on Business Organizations which provides as its primary business loans and a limited number of financial services to micro and small legal entities, low-income households and low-income persons". Central Bank of the Republic of Kosovo-CBK is the regulatory authority in charge of licensing, regulating and supervising all financial institutions (Note 3) (that includes MFIs). In addition, each entity that operates as NGO in Kosovo is subject to specific regulatory requirements highlighted by Law on Freedom of Association in Non-Governmental Organizations (Note 4).

As highlighted in the introductory part, virtually all (Note 5) of the MFIs in Kosovo are incorporated as NGOs, therefore not collecting deposits. As such, MFIs find particularly difficult funding their operations and as a result charging high interest rates while being vastly uncompetitive on their loans compared to licensed banks. Receiving funds or grants from donors in the future is dubious, posing so serious questions mark on the feasibility of their presence in Kosovo in the following years.

\section{Methodology}

The research on issues and challenges with regard to regulation and supervision of MFIs in Kosovo is done in a structured way in three steps.

1) First, the main challenging issues related to MFIs are selected and commented, so as to have a complete picture of the different existing weaknesses that have to be considered and solved.

2) After it, in a second step, each one of the main challenging issues is considered in a separate way, analyzing how the problem can be addressed and highlighting the relative pros and cons of the different available options when there is more than one, so CBK can make its own decisions with a well-funded knowledge. Notwithstanding it, a clear preference is always expressed by the authors in terms of what is considered to be the best and recommended option for each case, so the regulator can take these preferences as helping tools and relevant references for its own decisions. These preferences are summarized at the end of each challenging issue analyzed.

3) Finally, as the third step, conclusions are put together in the form of the proposed MFIs types, so as to synthesize the way the different challenging issues can be addressed and the regulation and supervision of MFIs be significantly improved and effectively adapted to the requirements of a stable and integrated financial system.

4) At the same time, some final considerations are also made in this last section in order to organize the transition from the current situation to the potentially desired one for the future.

5) In this way, it is considered that an effective intermediate balance in terms of professional approach can be achieved between two undesirable extremes, a too open approach, with too many options, on the one hand and a too strong recommendation, too close to an order or instruction, on the other hand. 


\section{Main Challenging Issues Related to Mfis in Kosovo}

The main challenging issued related to MFIs in Kosovo can be divided into two main parts. On the one hand, there are intrinsic challenging issues, related to MFIs nature. On the other hand, there are external problems, related to MFIs supervision and regulation.

The detail is as follows:

Challenging Issues Related to Mfis Nature (Intrinsic) weak corporate governance, mixed activities, financial restrictions, deposits collection, social nature of the legal vehicle used as an MFI and high lending interest rates.

Challenging Issues Related to Mfis Regulation and Supervision (Extrinsic) Insufficient supervisory policies and unclear regulatory competences and responsibilities (CBK and NGO office).

\section{Weak Corporate Governance}

According to Council of Microfinance Equity Funds (CMEF, 2012), "governance structure of MFIs closely mirrors ownership", that is to say lack of ownership in case of NGOs.

MFIs tend to have in practice weak corporate governance, almost by nature, mainly because of the following three main factors.

First of all, MFIs are usually small or very small institutions, where it is relatively quite difficult to have sound corporate governance, not only in what it refers to the establishment of effective control procedures and systems, but also in terms of the definition of clear lines of empowerment and responsibilities.

Secondly, there is usually a strong social component in this kind of institutions, derived from its foundation purpose, which too often tends to unduly prevail over the economic and financial aspects on the one hand and the organizational issues on the other hand.

Thirdly, the fact that these institutions are incorporated as NGOs in the context of social and economic development initiatives also tends to contribute in practice to weak corporate governance, as experience unfortunately shows in too many cases.

Finally, statutes and social charters of MFIs can also provoke significant corporate governance weaknesses, mainly due to a relatively naivety and lack of professional legal diligence in its conception and drafting. An example of it can be the case of MFI KEP Trust (Note 6), where the defined mechanisms for directors and top management successions and appointments were clearly inappropriate, in the sense of empowering acting individuals and not founders institutions or other companies to do it.

Corporate governance is, of course, very important for any institution, but it can be said that it is even more in the case of financial institutions, where poor corporate governance can derive, in a relatively easy and fast way, in its financial health and even its economic sustainability being seriously undermined, usually by granting bad loans and incurring in expenses much higher than needed, but also by direct fraud.

The situation is even worse in the case of those institutions that collect deposits from the public, as the potential crisis of a MFI with weak corporate governance has clear and dramatic external consequences on third parties in the form of financial losses.

\subsection{Way Forward}

The fact that MFIs tend to have poor corporate governance almost by nature does not mean at all that there is not much to do with regard to the regulatory reform, even if it has to be recognized from the beginning that it is not an easy task. In this sense, the question is not just issuing strict regulations on corporate governance, with strong associated requirements, but also giving incentives and helping to effectively promote corporate governance in different ways.

From this point on, there are several supervisory tools that can be used in the case of MFIs, given its specific circumstances.

First of all, a clear legal separation shall be made between financial institutions, whatever is its type and social and charity organizations. Financial institutions are subject to public regulation and supervision so as to ensure something critical for a country, a stable financial system, while social and charity organizations can operate on their own as long as they do not incur in illegal activities or commit crimes.

Accordingly, all types of financial institutions must have, amongst other requirements, good corporate governance in place to be allowed to perform financial activities. Saying it with different words, this is the price 
to pay to be considered and treated as a regular and registered financial institution that forms part of the financial system. If the price cannot be effectively paid, the institution cannot be a formal financial institution, but anything else.

This can be seen as a prohibition, but also as an incentive, in the sense that those institutions that want to be considered and perform financial activities on a regular basis must know that to get so they must conduct their business in a sound and organized way.

This consideration takes us to the second tool, the founders commitment and responsibility. This means that the founders can be used and act as promoters of good corporate governance, not only because it is directly beneficial to them, especially in terms of their reputation and a correct use of the divested funds, but also because it will allow the founded institution to be considered and perform as a regular financial institution.

In this sense, if the founders are not willing to do so or they are not capable of doing it effectively, a clear regulatory response must be given in the sense of not considering those MFIs as financial institutions subject to public regulation and supervision. It must be observed that this circumstance can seriously affect the founders in terms of eligibility, formal and substantial, to make their investments.

Quite close to this second tool is the third one, the main creditors, especially those with a multilateral or international institutional profile and specific purpose credit lines ("institutional creditors"). For similar reasons as the founders, reputation and a correct use of the lent funds in this case, the institutional creditors can also act and be used as promoters of good corporate governance. Furthermore, eligibility can be even a more sensitive issue for them, in the sense that in many cases only regular financial institutions can formally receive their loans.

Finally, the fourth tool is the statute or social charter of the MFI, the main internal and private regulation for corporate governance, which should be clearly designed and drafted so as to ensure that complying with them means good corporate governance and not the opposite, as it was the case of IMF KEP Trust, something that can be achieved establishing specific requirements on them.

Notwithstanding all of it, it must also be highlighted that corporate governance requirements for small companies cannot be exactly the same as those for large companies, or as recommended by BCBS (2010), such requirements shall be commensurate to the type and size of their transactions (BCBS 2010).

While the spirit and substance must obviously be the same, formal requirements should be adapted to the specific characteristics of small companies, so good corporate governance can be ensured without requesting more than what is really needed.

Accordingly, the regulatory reform shall consider;

Allowing as financial institutions only those MFIs capable of demonstrable good corporate governance and leave the rest as social and charity organizations without public registration and supervision.

Adapting corporate governance requirements to small companies, so principles can be effectively met without unnecessary formal requirements typical of larger organizations.

Deeply involve both founders and institutional creditors in MFIs corporate governance, either by directly participating in its control and management and by effectively requiring the MFIs to have good corporate governance in place to receive financial support.

Ensure that MFIs statutes and social charters are well designed and drafted, establishing specific requirements on them so that its compliance imply good corporate governance.

\subsection{Mixed Activities}

MFIs tend to simultaneously perform different activities, mainly as a consequence of its general purpose of social and economic development and its incorporation as NGOs.

While this has to be praised from a social point of view, as they are trying to improve the situation as much as possible in many different fronts, it cannot unfortunately deserve a good consideration at all from a supervisory point of view, as purely financial activities are mixed with other economic and even non-economic activities, making it quite difficult to unravel the tangle too many times.

The already commented fact of usual poor corporate governance typical of MFIs does not help at all, but just the opposite, as it makes the situation even more complex, both in theory and practice. 


\section{Way Forward}

BCBS on the Core Principles suggest that "the permissible activities of institutions that are licensed and subject to supervision as banks must be clearly defined" (BCBS, 2010). In Kosovo case the best way to address this problem is to do it in a direct, simple and radical way, in a sort of undoing the Gordian knot, by requiring MFIs that want to be considered as regular financial institutions to perform only financial activities and to have and use other differentiated legal vehicles for the rest of activities and purposes.

In fact, requiring financial institutions to exclusively perform financial activities on the one hand and not allowing other kind of institutions to perform financial activities on the other hand, is one of the "main principles of a sound supervisory system" (BCBS, 2010), not only in what it refers to licensing, but also to supervisory practices on an ongoing basis.

From this point on, we identify several ways to achieve this radical separation, from using other related companies and institutions for non-financial activities to creating a specific legal vehicle to perform financial activities. While it must be the MFI who must decide how to do so, it is the supervisor's duty to ensure that, one way or another, there is finally a licensed financial institution that performs only financial activities.

This objective has to be met both in theoretical and practical terms. This means that it is not enough to have a specific formal vehicle for financial activities, but also that the financial institution is clearly isolated in practice from other existing legal vehicles and activities so it does not get contaminated by them.

This is recommended to be done in quantitative terms, using prohibitions, limits and similar measures for transactions between the financial institution and the rest, but also in qualitative terms, ensuring that management decisions of the financial institutions are not unduly influenced by what is being done through the other legal vehicles, especially preventing in this sense potential conflicts of interest. In other words, apart from the requirement of having a specific legal vehicle to perform financial activities, regulations must be issued to effectively ring-fence the financial institution, in quite a similar way to what is done in the case of financial institutions linked to large industrial and commercial groups or in the case of local financial subsidiaries of foreign challenging financial groups.

Again, as in the previous case, it is up to the MFIs to decide if they want to abide by these rules or not, in the sense that they must clearly realize that it is a "sine qua non" requirement to be a regular financial institution, so if they decide not to separate activities they must know that this implies their voluntary renounce to be a formal financial institution and their preference for social and charity organizations.

\section{Accordingly, the regulatory reform shall;}

Require MFIs that will be considered as financial institutions to perform only financial activities.

Establish quantitative and qualitative prudential mechanisms, as prohibitions and limits on the one hand and rules for prevention of conflicts of interest on the other hand, to ensure an effective isolation of the financial institution from other related activities and institutions.

\section{Financial Restrictions}

Almost by nature, MFIs tend to have significant financial restrictions to develop their business. The main restrictions are related to the following important subjects:
1) Capital.
2) Funding.
3) Profitability.
4) Liquidity.

Capital restrictions are derived from the fact that MFIs do not have shareholders or capital in a strict sense, but grants or foundation donations. This means that MFIs only ways to increase capital is through profits retention or by additional grants or donations.

If MFIs do not have profits or do not receive additional grants or donations, its capital base will remain always the same. Consequently, if this is the case, it implies that its business size cannot increase, even in nominal terms.

Furthermore, if there are regular significant losses, the capital base will continuously decrease and, accordingly, the business size will also have to be regularly lowered, with all the implications it has, not to mention the 
prospect of a potential crisis. However, it can be certainly said that the situation is not so different to that from banks, as they have to increase their capital also from retained earnings and extraordinary capital increases.

Notwithstanding it, it is also true that banks are not allowed from a supervisory point of view to incur regularly in losses, as well that banks are asked to have explicit financial support from their shareholders. It is not so clear that these two requirements are always requested from MFIs with the same clarity and firmness.

Funding restrictions are also very relevant to MFIs for several reasons. First of all, MFIs are not usually allowed to collect deposits from the public, as it is the case in Kosovo, or, at least, to do so in the same degree and conditions. Secondly, MFIs do not have access to interbank or wholesale markets, but have to rely on donors and institutional creditors. Thirdly, funding can be provided in foreign currency, causing so potential foreign exchange problems and even significant losses, even if lending is granted in the same foreign currency. This means that MFIs can have significant financial bottlenecks if fluid and adequate funds streams cannot be obtained from donors and institutional creditors.

Thirdly, profitability is also usually an issue for MFIs, not so much in terms of not being able to be profitable in absolute terms, but in the quite different prevailing conditions for them compared to banks.

In this sense, while it is true that MFIs tend to charge significant higher interest rates for their loans, it is also true that operating expenses and loan losses provisions tend also to be significantly higher, in a kind of scale change of conditions. At the same time, while one should expect more favorable conditions for their funding, considering the kind of creditors and the donors, this is not always true, apart from the fact that MFIs do not really have the most common and cheapest way of financing, that is through current and saving accounts.

Finally, liquidity can also be a problem, although usually more related to business continuity and not so much to liabilities, as MFIs do not have the deposits liquidity aspect on the one hand and institutional financing tends to be clearly linked to the loan portfolio origination and development.

There is no easy way to address these restrictions, as they are mainly structural and typical of MFIs. However, at the same time and in a similar way to what was proposed in terms of corporate governance, some useful actions can be taken from a regulatory and supervisory perspective to improve the situation.

The most important and general one is to fix the maximum acceptable levels for these restrictions for those MFIs that can be considered as financial regulated institutions. Even though it is true that some adaptation of the general rules for banks has to be made, this adaptation cannot cross the red line of what is not considered adequate at all for financial institutions. Accordingly, the crucial point is to fix the adequate levels for MFIs, taking into account at the same time their specific and structural characteristics and the minimum acceptable for financial institutions.

In terms of capital, this general principle can be specifically translated by saying that:

1) MFIs must have adequate capital in terms of their business and the incurred risk levels (risk based capital), following the same rules applicable to a bank, although considering the specific kind of business of MFIs and the associated risk levels and capital requirements for it. Usually, given the higher risk of its business, this would imply that MFIs should have higher capital levels in relative terms ( $\%$ of assets).

2) MFIs must be profitable enough on a regular basis to be able to retain enough profits to cover additional capital requirements derived from the new (increased) business.

3) Something similar, although in not so strict terms, can be said in terms of explicit financial support from the controllers/owners to cover potential needs of capital increase. If this support cannot be provided, the supervisor should be empowered to restrict MFIs operations, in quantity and quality, and, ultimately, to force its transformation.

In terms of funding, the general principle can be specifically translated by saying that:

1) MFIs should have fluid funds streams from donors and institutional creditors, not only in an operational sense, but also from the point of view of contracts and other legal commitments.

2) These funds streams should be proportionate and adequate to the business performed, both in terms of amounts and terms. If funding is provided in a foreign currency, it must be ensured that there will be no problems to change from one currency to another and that no significant foreign exchange losses can result to the MFIs (direct or indirectly).

In terms of profitability, the general principle can be specifically translated by saying that: 
1) MFIs should effectively define a realistic and feasible profitability structure taking carefully into account its specific factors, especially interest rates (charged and collected), operational expenses and loan loss provisions.

2) Connected to capital restrictions, this profitability structure should ensure that enough profits can be made and retained to ensure a swift business development and organic growth.

Finally, liquidity should also be considered, especially in terms of business continuity and normal operations development, taking into account in this context the former requirements, especially those related to funding.

Accordingly, taking into account the former considerations, regulations shall:

1) Ensure that the proposed minimum conditions for capital, funding, profitability and liquidity of MFIs are effectively met.

2) In those cases where these conditions are not met, those MFIs should not be treated anymore as financial institutions, but forced to be converted into social and charity organizations.

Financial intermediation between depositors and borrowers is the most traditional and typical banking activity. Furthermore, even in the context of a free market economy, this function is legally reserved to banks, considering it a restricted economic activity that must be subject to intense public regulation and supervision, including the previous licensing process.

However, being more precise, what is really usually restricted to banks and subject to authorization is just the collection of deposits from the public, as lending can be made in many cases by any company or individual as far as it is not made with money from depositors.

The reasons for it are well known, so it is not necessary to insist on it and, in fact, many regulations clearly emphasize and highlight this point, explicitly defining the protection of deposits and depositors as one of the main objectives, if not the most important one, of the supervisory legal framework.

From this point on, the question is if MFIs should be allowed to collect deposits from the public and, in case they are, to what extent. Or, saying it with different words, how different should be in practice an MFI from a bank, especially a small one.

\subsection{Way Forward}

In this context, it is important to begin stressing that, while the traditional concept of microcredit was basically restricted to granting loans of small amounts to people with limited or no access to lending, modern conceptions go much further, in terms of providing this kind of people with a broader range of financial services, so as to help them to put an end to their financial exclusion and favor as such their social and economic integration in the society.

This range of financial services begins of course with lending, so as to provide this people an economic opportunity to improve their situation through a business project financing, but also includes, even if at a further stage and a limited amount, current accounts and deposits to better integrate them through the introduction of an organized savings culture, as well as insurance services to cover potential future economic losses in their economic activities.

Accordingly, a modern conception of an MFI cannot be limited to lending, but should also include other financial activities, namely deposit collection, transforming then MFIs in financial institutions quite similar to banks in terms of the range of financial services they should provide to their customers.

However, even in this modern conception of microcredit, there is a significant difference between MFIs and banks, in the sense that MFIs should have by nature a gradual and relatively global approach to their customers, progressively increasing the range of financial services provided to each of them, something that banks do not require, as they can have different types of customers with different financial needs and behave more like product sellers (e.g., in the case of individuals, a simple division can be made between depositors and borrowers).

This means that MFIs could be allowed in this context to collect deposits, although only up to a limited amount per individual and only from customers who have been granted loans before, in a sort of unofficial membership.

This would imply giving MFIs a specific and characteristic financial role, different to the generic one attributed to banks, even the smaller ones, and would give also a broader and more effective sense to their contribution to the financial improvement of those segments of the population in serious risk of financial exclusion. 
What does not seem to have other explanation than a tactical compromise is to allow MFIs to collect deposits with an absolute limit, regardless of the amount per customer, as this can mean in practice to have MFIs operating in practice as small banks, but without the same requirements.

Accordingly, it is proposed that MFIs should be allowed to collect deposits subject to the following conditions:

1) Limited amounts per individual.

2) Only from individuals that have been previously customers as borrowers.

\section{Mfi's Social Nature and Ownership}

As already commented, given their origin, it cannot be a surprise at all that MFIs are NGOs in terms of its social type of incorporation.

This kind of social nature is especially useful for difficult and unstable contexts, as it can be easily and quickly adapted to dramatic changing conditions, but tends to reveal as inadequate as soon as the situation improves and stabilizes, as it is fortunately the case of Kosovo.

In fact, almost all the challenging issues related to MFIs that have been previously commented derive from this NGO social nature, especially in what it refers to poor corporate governance and financial restrictions, as it has been analyzed in detail.

From this point on, it is clear that something has to be done in terms of the social nature of MFIs, so as to effectively adapt it to the minimum needs of a consolidated and formal financial institution.

\subsection{Way Forward}

The most immediate way, although not the most effective one, to address the problem is to force NGOs to transform themselves into mercantile companies, in the same way as it is required for banks. Within such context, "transformation (Note 7) is the process whereby NGOs, or other formal or informal microfinance providers, convert to a regulated financial institution" (Portocarrero, 2011).

A similar option in substance, although not in form, would be to require those NGOs performing financial activities to directly comply with the same requirements as any mercantile company that is allowed to be the owner or main controller of a bank.

However direct and apparently simple these options are, it seems they are more a wishful thinking than a realistic approach, as problems cannot be resolved just simply stating what is desired, as it is also necessary to define how to get to it. Furthermore, even if from an opposite point of view, it must also be said that the social aspect of this kind of financial institutions should be preserved in some way, recognizing on the one hand the important contribution made and avoiding on the other hand potential improper benefits for certain individuals that can be well positioned to take undue advantage of a significant change of the situation.

In this sense, it is interesting to see that this kind of problem is not new at all in the context of financial supervision. A recent and relatively close example of this kind of situation is the evolution of the savings banks model in Western Europe, where a solution was designed to be able to solve and make compatible both the economic and social aspects of the problem.

Applying this solution to MFIs in Kosovo, would imply:

a. Creating a new legal vehicle, a company, as a financial institution to perform all and only financial activities.

b. Allowing the NGO to be the owner of this new legal vehicle-financial institution.

c. Transferring or segregating the financial business from the NGO to the new financial institution.

d. Providing the new financial institution with adequate and independent professional control and management.

This solution would have the following main advantages:

a. The new company would be subject, in theory, but also in practice, to all the applicable needed quantitative and qualitative requirements of a regular financial institution.

b. The NGO would maintain ownership and receive dividends for other social purposes if there are enough profits after reserves retention for capital adequacy requirements, in a similar way to a foundation.

Additionally, even if for the future, this framework would easily allow for ownership changes from NGOs to private capital, whether it is a full ownership change or just a partial one in the sense of new shareholders. 
However, as potential disadvantages, it must be said that there can be substantial tax costs related to the business transmission as well as certain legal difficulties to NGOs having subsidiaries. Notwithstanding it, given the transcendence of the reform, it is suggested these disadvantages could be overcome by a new regulation specific for MFIs.

Accordingly, it is proposed that legal reform would allow for the creation of new legal vehicles, fully owned by $N G O s$, to perform financial activities as regular financial institutions.

\section{High Lending Interest Rates}

MFIs lending interest rates in Kosovo are significantly higher in absolute terms than the correspondent ones charged by banks (average MFI interest rate 22.3\% \& average bank interest rate 7.7\%, CBK, 2015 (Note 8)). This is seemingly the case of almost all MFIs around the world and "they do so (mostly) on account of the realities of the microfinance business" (Asian Development Bank-ABD, 2016). According to CGAP (2004) "Unless micro-lenders can charge interest rates that are well above average bank loan rates, they cannot cover their costs, and their growth and sustainability will be limited by the scarce and uncertain supply of subsidized funding".

However, it is not so clear if MFIs interest rates are also significantly higher in relative terms, taking account of its objective specific circumstances in terms of:

1) The type of clientele and lending operations, which can imply higher credit risk and, consequently, higher costs in terms of loan loss provisions.

2) The cost of funding for MFIs, who do not have the same access to relatively cheap deposits as banks.

3) The relatively low amount of loans, which can cause higher operational expenses.

Furthermore, with a relatively objective nature, as it can be clearly linked to MFIs typical profiles, there are also professional inefficiencies and organizational weaknesses that can explain these higher rates.

Accordingly, to have a fair evaluation of MFIs lending interest rates in relative terms, it is suggested to evaluate this issue in terms of the final profitability of MFIs, so as to take into account all the relevant costs. This procedure would also have the additional advantage of evaluating the minimum lending interest rates levels that MFIs should charge to ensure their practical financial and economic sustainability.

\subsection{Way Forward}

The following actions can be taken to address the situation of higher interest rates.

First of all, experience shows that only increased competition between financial institutions and, to a lesser extent, financial education of customers, can really solve the problem, as these factors clearly influence supply and demand and, consequently, price (rates) formation. Mersland and Strøm (2008) found that increased levels of competition in microfinance markets induced efficient operations and reduced interest rates. However, these factors tend to produce effective results mainly in the long term, so in short term, other measures can be arbitrated.

The first one is based on improving consumer protection (financial services users' protection in a more precise terminology), basically through:

1) Increasing transparency in the MFIs' communications of interest rates to their customers, both on a general (advertisements, announcements boards and websites) and individual basis (contracts and other legal documents).

2) Promoting homogeneity in interest rates calculations made by different financial institutions (both banks and MFIs) setting standard methods for it.

Finally, anti-usury general mercantile regulations can also be used in this context, although it must be realized that maximum legal interest rates levels should be defined so low that they could imply that MFIs would not be economically sustainable. Furthermore, this measure should not be confused at all with interest rates administrative capping in a sort of obsolete administrative regulation of interest rates.

Accordingly, it is suggested to take the following actions:

1) In the long term, promote competition between financial institutions and financial education of customers.

2) In the short term, promote consumers protection through increased transparency and homogeneity in financial calculations of interest rates. 
3) As a general measure, use anti usury general mercantile regulations.

\section{Insufficient Supervisory Policies}

Even though it cannot be said at all that MFIs are not supervised, apparently there are not specific and complete supervisory policies in place for them, but just a too general approach, mostly based on inertia and available resources.

As such, MFIs supervision seem to be a clear second priority after banks, allocating resources to these tasks as much as an effective banking supervision allows, in a sort of "second division" playfield.

At the same time, there are no clear supervisory objectives for MFIs, nor specific procedures or methodologies for it, but more the kind of work the available resources and time really permit.

\subsection{Way Forward}

A clear definition should be made in terms of specific supervisory policies for MFIs. This definition should consider, as in any supervisory strategy, the desired objectives on the one hand and the available resources on the other hand.

Obviously, being realistic, both objectives and resources for MFIs supervision have to be determined taking as well into account banking supervision policies and strategies, although not in a residual form, but on a simultaneous and parallel basis.

From this point on, different supervisory policies and strategies should be defined for the different types of MFIs (see final section), taking into account the different risks of each type and the adequate supervisory responses, in terms of differential actions and intensities for each of them.

These supervisory policies and strategies can accordingly vary from being very similar to those defined for banks in those cases where MFIs can be assimilated and fully comparable to being practically null in those cases where no supervision is considered necessary.

In this context, the most specific supervisory policies and strategies will be for those intermediate cases where MFIs precisely show their most specific characteristics as financial institutions, in the sense of being small institutions with a clearly specialized activity, a well-defined low segment clientele and a relatively high number of operations with a low individual absolute amount.

In these cases, it is suggested to focus policies and tasks in terms of quality assessments, especially in what it refers to corporate governance, including control systems and procedures, and business performance.

Finally, in terms of procedures, it is strongly recommended to use sampling and peer reviews analytical techniques.

Accordingly, it is proposed to define specific policies, strategies and procedures for MFIs, taking account of its specific characteristics and prevailing types, coordinating them with banking supervision on a parallel basis.

\section{Unclear Regulatory Competences}

MFIs are subject to two different regulators. On the one hand, as financial institutions, they are regulated and supervised by CBK, while, on the other hand, as NGOs, they are subject to the NGO office (Note 9) under Ministry of Public Administration.

However, the main problem is not so much having two regulators, but the absence of clear rules defining the competences and responsibilities of each of them, so regulatory initiatives have to be adopted in common under a voluntary consensus basis.

Additionally, increasing the problem, there is a clear difference between the two regulators in terms of professional competence and dedication, as CBK clearly is in a more adequate situation to fulfill its duties.

\subsection{Way Forward}

While the only workable solution in the short term seems to be actions based on voluntary consensus, it is considered both desirable and necessary to improve the situation in the medium term, as recent events clearly show. The most immediate way to do so would be to agree an effective Memorandum of Understanding between the two regulators, where the respective competences and responsibilities could be clearly defined on the one hand and coordination mechanisms enabled on the other hand.

However, given the prevailing circumstances, especially those related to the different professional competence and dedication, this option seems to be more theoretical than practical. 
So, even being also difficult, it seems more pragmatic for CBK to react gaining distance and marking its territory in regard to the NGO office in practical terms using its professional advantage and a "fait accompli" strategy, which can award to CBK at the same time the respect of MFIs, including its founders and institutional creditors.

Notwithstanding it, the best way to address this problem is to issue regulations creating different regulatory playing fields for each regulator, so interferences and potential confusions can be kept to a minimum.

This can be considered as extremely difficult or even impossible in itself, but it is not at all in the case that the former proposal for the configuration of NGOs as owners of specific financial institutions called MFIs is accepted.

In this case, almost by definition, the respective competences and responsibilities can be clearly defined, as CBK would be fully responsible for MFIs as financial institutions, in the same way as for banks, while the NGO office would be just in charge of the owners, the NGOs.

Accordingly, it is proposed to establish, at least in practice, operational autonomy from the NGO office. This can be easily obtained, almost automatically, if the proposal for the configuration of NGOs as owners of specific financial institutions called MFIs is accepted.

\section{Proposed Types of MFI's}

Taking into account the former considerations and suggestions, it is proposed to define the three following types of MFIs:

1) MFIs with the same requirements and allowances than a bank, even if their size is relatively small (micro-banks).

2) MFIs subject to specific regulations, with less requirements and, consequently, allowances than a bank (pure MFIs).

3) MFIs not subject to regulation and supervision (NGOs or social and charity organizations).

\subsection{MFI's-Micro Banks}

The first type, the MFIs-micro-banks, would be considered as banks, up to the point of being fully and directly subject to the banking law. Accordingly, these institutions would be allowed to use the name of "bank" and be issued a banking license.

Only those MFIs that can effectively comply with all the requirements established for banks would be able to apply for this consideration. This means that these institutions must overcome all the different intrinsic challenging issues related to MFIs mentioned in this note (except the last one related to high lending interest rates). Most particularly, these institutions should transform into a mercantile company, being its initial owner the NGO.

In this context, it is recommended that these institutions should be subjected to a formal and rigorous banking license application process to ensure that all requirements are effectively met.

Depending on the circumstances, the banking license can be restricted in terms of allowed financial activities, according to the list contained in the law, especially in what it refers to deposits collection (types and amounts). These restrictions can be temporary (e.g., for the first five years) or permanent (until a new authorization is given), although the latter type is not recommended.

\subsection{MFI's-Pure MFI's}

The second type, MFIs subject to specific regulations, which can be called "pure MFIs", should have an intermediate status between "MFIs-microbanks" and "MFIs-NGOs or social and charity organizations".

This means that these institutions would be subject to less requirements and, consequently, allowances than a bank on the one hand, but would have to show significant improvements in terms of the intrinsic challenging related issues compared to the "MFIs-NGOs or social and charity organizations" on the other hand.

The main incentives for this kind of financial institution are operational (including deposits collection, even if limited) and reputational (supervised by CBK).

More specifically, consideration as a "pure MFI" implies:

1) In terms of corporate governance, these MFIs should be capable of demonstrable good corporate governance, even though this kind of requirements should be adapted to small companies, so principles can be effectively met without unnecessary formal requirements typical of larger organizations. Additionally, 
both founders and institutional creditors should be deeply involved, with MFIs statutes and social charters well designed and drafted.

2) Regarding activities, these MFIs would not be allowed to perform other activities than the financial ones mentioned in their license. In case there are other related activities and institutions, effective quantitative and qualitative prudential mechanisms should be in place to ensure an effective isolation of the financial institution.

3) In what it refers to financial restrictions, these MFIs should ensure that minimum conditions for capital, funding, profitability and liquidity are effectively met, although it can be in a specific way.

4) These MFIs would be allowed to collect deposits, although on a limited amount per individual and only from individuals that have been previously customers as borrowers.

5) Finally, in terms of social nature and ownership, new legal vehicles, fully owned by NGOs, should be created to perform financial activities as regular financial institutions.

\subsection{MFI's-NGOs Social and Charity Organization}

The third type of MFIs, the "MFI-NGOs or social and charity organizations", will be formed by all those MFIs that do not comply with the requirements to be a "pure MFI" and/or do not wish to do so. Those MFIs whose future sustainability is doubtful because no new grants or funds are expected should be classified here.

These MFIs will not be formally considered anymore as financial institutions. Accordingly, these MFIs will not be subject at all to financial regulation or supervision by CBK, nor be formally registered by it, although CBK should be empowered to:

1) Request statistical data on a periodical or sporadic basis.

2) Inspect them to verify that these MFIs are not performing financial activities restricted to other kind of financial institutions or unduly using reserved denominations with customers and counterparties (especially institutional creditors) or presenting themselves as authorized or registered by CBK.

In case these MFIs perform financial activities restricted to other kind of financial institutions, use reserved denominations with customers and counterparties or present themselves as authorized or registered by CBK, it should be considered as an illegal financial performance, consequently subject to sanctions and penalties.

\section{Transitional Issues}

Prior to any regulatory modification, a full analysis in depth of the existing MFIs should be performed, so as to check the new framework practical adequacy, including which MFIs would be ascribed in principle to each category and which ones could effectively improve to higher level classes.

This analysis should also cover qualitative aspects, like the adequacy of corporate governance, including social charters and statutes.

Existing MFIs diagnosis and analysis can be used with this purpose, whether they are general or not.

\subsection{Banking Map}

Taking into account that banks and MFIs represent the vast majority of financial institutions performing banking activities, a serious reflection should be made in terms of other similar kind of financial institutions with banking type activities, so as to decide if these categories should be kept, modified or suppressed in the context of a consistent banking map for Kosovo.

\section{References}

Asian Development Bank. (2016). "Impact of Restrictions on Interest Rates in Microfinance"-ABD. Sustainable Development Working Paper Series, 45.

Basel Committee on Banking Supervision. (2010). Microfinance Activities and the Core Principles for Effective Banking Supervision. Bank for International Settlements-BIS.

Central Bank of the Republic of Kosovo. (2011). Annual Report. Retrieved from http://bqk-kos.org/repository/docs/2013/CBK-AR-2011.pdf

Central Bank of the Republic of Kosovo. (2015). Annual Report. Retrieved from http://bqk-kos.org/index.php?id=102

Christen, P. R., \& Rosenberg, R. (2003). The Rush to Regulate—Legal Framework for Microfinance. 
Council of Microfinance Equity Fund. (2012). The Practice of Corporate Governance in Microfinance Institutions.

Dahir, M. A. (2015). The Challenges Facing Microfinance Institutions in Poverty Eradication-A Case Study in Mogadishu.

Greuning, H., Gallardo, J., \& Randhawa, B. (1998). A Framework for Regulating Microfinance Institutions - Financial Sector Development Department. The World Bank.

Hermes, N., Lensink, R., \& Meesters, A. (2011). Outreach and Efficiency of Microfinance Institutions. Elsevier Ltd.

Lauer, K. (2008). The Consultative Group to Assist the Poor-CGAP.

Mersland, R., \& Strøm, R. O. (2008). Performance and trade-offs in microfinance organizations-Does ownership matter? Journal of International Development, 20,

Official Gazette of the Republic of Kosovo. (2009). Law No. 03/L-134 on Freedom of Association In Non-Governmental Organizations. Retrieved from http://www.gazetazyrtare.com/e-gov/index.php?option=com_content\&task=view\&lang=en\&id=333

Official Gazette of the Republic of Kosovo. (2012). Law No. 04/L-093 on Banks, Microfinance and Non-bank Financial Institutions. Retrieved from https://gzk.rks-gov.net/ActDocumentDetail.aspx?ActID=2816

Otero, M. (1989). A handful of rice. Savings Mobilization by Microenterprise Programs and Perspectives for the Future. Action Internationale, World Bank, Washington.

Portocarrero, F. (2011). MFI Transformations: The LAC Experience. Valladolid, Spain.

Robinson, M. S. (2001). The Microfinance Revolution-Sustainable Finance for the Poor. The World Bank, Open Society Institute.

The Consultative Group to Assist the Poor-C-GAP. (2003). Guiding Principles on Regulation and Supervision of Microfinance. In Microfinance Consensus Guidelines. Washington: CGAP.

The Consultative Group to Assist the Poor-C-GAP. (2004). Key Principles of Microfinance. Washington: CGAP.

The Consultative Group to Assist the Poor-C-GAP. (2006). Good Practice Guidelines for Founders of Microfinance. Washington: CGAP.

The Consultative Group to Assist the Poor-C-GAP. (2010). Regulation \& Supervision of Microfinance Institutions: Stabilizing a New Financial Market.

\section{Notes}

Note 1. UNMIK=United Nations Mission in Kosovo. The mandate of the United Nations Interim Administration Mission in Kosovo (UNMIK) was established by the Security Council in its resolution 1244 (1999).

Note 2. Veton Zeqiraj-Central Bank of the Republic of Kosovo Garibaldi str. no.33 Prishtinë, Kosovo.

Note 3. Law No.03/L-209 on Central Bank of the Republic of Kosovo.

Note 4. Law No.03/L-134 on Freedom of Association in Non-Governmental Organizations.

Note 5 . All but one.

Note 6. CBK-Annual Report 2011, Examination of KEP Trust, conducted in the last quarter of 2010, re-emphasized the shortcomings previously evidenced (2009), and which mainly related to the governance of the institution. These shortcomings, carried on for a considerable period of time, by the end of 2010, resulted in lack of authorizations, respectively of legitimacy of control and management structures of the microfinance institution KEP Trust. The whole this problem became more evident from the reserved positioning, lack of consensus and later on by the abandonment of the institution by its founder himself, thus disbanding the entire necessary governing structure. Consequently, with purpose of avoiding such shortcomings evidenced and maintaining the liquidity and solvency capacity of the institution, the CBK had to impose the measure of temporary administration in the beginning of 2011 (http://bqk-kos.org/repository/docs/2013/CBK-AR-2011.pdf).

Note 7. See appendix 1 and 2 on examples of transformation from NGO to commercial companies.

Note 8. CBK, annual report 2015. 
Note 9. http://map.rks-gov.net/Departments/DOJQ.aspx?lang=en-US

\section{Appendix}

Appendix 1. Transformation of NGO MFIs-Country based

\begin{tabular}{|c|c|c|c|}
\hline Country & First transformation & Last transformation & Total nr. \\
\hline \multicolumn{4}{|l|}{ Regional Countries } \\
\hline Albania & 1999 & & 1 \\
\hline Bosnia & 2007 & 2007 & 3 \\
\hline Kosovo & 2004 & & 1 \\
\hline Macedonia & 2000 & & 1 \\
\hline Montenegro & 2002 & 2006 & 2 \\
\hline Serbia & 2006 & & 1 \\
\hline \multicolumn{4}{|l|}{ Other Countries } \\
\hline Armenia & 2006 & 2006 & 3 \\
\hline Azerbaijan & 1996 & & 1 \\
\hline Bangladesh & 2001 & & 1 \\
\hline Bolivia & 1992 & 1999 & $\begin{array}{l}5+1 \text { second stage transformation-sst } \\
(2005 \text { (Note) })\end{array}$ \\
\hline Cambodia & 2000 & 2004 & 1 \\
\hline Columbia & 1993 & & 1 \\
\hline Dominican Republic & 1998 & & 1 \\
\hline Ecuador & 2004 & & 1 \\
\hline El Salvador & 1995 & & $1+1$ sst (2004) \\
\hline Georgia & 2007 & 2007 & 4 \\
\hline Ghana & 1994 & 2004 & 2 \\
\hline Haiti & 2004 & & 1 \\
\hline Honduras & 2000 & & 1 \\
\hline India & 2000 & 2007 & 7 \\
\hline Kazakhstan & 2005 & 2007 & 2 \\
\hline Kenya & 1999 & & 1 \\
\hline Kyrgyzstan & 2003 & 2005 & 3 \\
\hline Lebanon & 2006 & & 1 \\
\hline Mexico & 2001 & 2001 & $1+1$ sst (2006) \\
\hline Mongolia & 1999 & 2001 & $1+1$ sst (2001) \\
\hline Nepal & 1999 & 2002 & 3 \\
\hline Nicaragua & 2000 & 2003 & $3+1$ sst (2004) \\
\hline Pakistan & 2002 & & 1 \\
\hline Peru & 1997 & 2001 & 10 \\
\hline Philippines & 1997 & 2002 & 4 \\
\hline Romania & 2006 & 2006 & 3 \\
\hline Russia & 2005 & 2005 & 2 \\
\hline Sierra Leone & 2005 & & 1 \\
\hline
\end{tabular}




\begin{tabular}{|c|c|c|c|}
\hline Uganda & 2004 & 2005 & 4 \\
\hline 35 countries & & & 84 \\
\hline
\end{tabular}

Note. A second-stage transformation is the transformation of a for-profit company that had already transformed from an NGO into a bank.

Appendix 2. Transformation of NGO MFIs, institutions based

\begin{tabular}{|c|c|c|c|c|c|c|}
\hline Year & $\begin{array}{l}\text { Nr.oftr } \\
\text { ns. in a } \\
\text { year }\end{array}$ & $\begin{array}{l}\text { Name of transforming } \\
\text { institution or project }\end{array}$ & $\begin{array}{l}\text { INGO or Other, International, } \\
\text { Founder, Network, or TA } \\
\text { Provider (Note) }\end{array}$ & $\begin{array}{l}\text { Name of New, Financial, } \\
\text { Institution }\end{array}$ & $\begin{array}{l}\text { Type of Formal, } \\
\text { Financial, } \\
\text { Institution }\end{array}$ & Country \\
\hline 1992 & 1 & $\begin{array}{l}\text { Promoción y } \\
\text { Desarrollo de la } \\
\text { Microempresea } \\
\text { (PRODEM) }\end{array}$ & $\begin{array}{l}\text { ACCION } \\
\text { International }\end{array}$ & BancoSol & Commercial Bank & Bolivia \\
\hline 1993 & 1 & $\begin{array}{l}\text { Corposol(dissolved in } \\
\text { 1996) }\end{array}$ & & $\begin{array}{l}\text { Finansol (restructured and } \\
\text { renamed FINAMERICA in } \\
\text { 1997) }\end{array}$ & $\begin{array}{l}\text { Commercial } \\
\text { Finance Company }\end{array}$ & Colombia \\
\hline 1994 & 1 & $\begin{array}{l}\text { Women's World } \\
\text { Banking Ghana }\end{array}$ & $\begin{array}{l}\text { Women's World Banking } \\
\text { (WWB) network }\end{array}$ & $\begin{array}{l}\text { Mutual Assistance Susu } \\
\text { Savings \& Loan }\end{array}$ & $\begin{array}{l}\text { Savings and Loan } \\
\text { Company }\end{array}$ & Ghana \\
\hline \multirow[t]{2}{*}{1995} & 2 & Procredito & $\begin{array}{l}\text { Internationale Projekt Consult } \\
\text { GMBH (IPC) (TA provider) }\end{array}$ & Caja Los Andes & $\begin{array}{l}\text { Finance Company } \\
\text { (FFP) }\end{array}$ & Bolivia \\
\hline & & AMPES & & FinancieraCalpiá & Finance Company & El Salvador \\
\hline 1996 & 1 & $\begin{array}{l}\text { AzerCredit } \\
\text { (project) }\end{array}$ & $\begin{array}{l}\text { World Vision } \\
\text { International (WVI) }\end{array}$ & $\begin{array}{l}\text { WV AzerCredit } \\
\text { LLC }\end{array}$ & NBFI & Azerbaijan \\
\hline \multirow[t]{3}{*}{1997} & 3 & SEPAR & & $\begin{array}{l}\text { EDPYME } \\
\text { Confianza }\end{array}$ & RFI & Peru \\
\hline & & CARE Peru & CARE & $\begin{array}{l}\text { EDPYME } \\
\text { EDYFICAR }\end{array}$ & RFI & Peru \\
\hline & & CARD & & CARD Rural Bank & Rural Bank & Philippines \\
\hline \multirow[t]{5}{*}{1998} & 5 & FIE & & $\begin{array}{l}\text { FIE Fundo Financiero } \\
\text { Privado }\end{array}$ & FFP & Bolivia \\
\hline & & Ademi & & Banco ADEMI & $\begin{array}{l}\text { Development } \\
\text { Bank }\end{array}$ & $\begin{array}{l}\text { Dominican } \\
\text { Republic }\end{array}$ \\
\hline & & $\mathrm{ACP}$ & $\begin{array}{l}\text { Accion International } \\
\text { (TA provider) }\end{array}$ & MiBanko & Commercial Bank & Peru \\
\hline & & $\begin{array}{l}\text { Habitat Arequipa } \\
\text { Siglo XXI }\end{array}$ & Habitat & $\begin{array}{l}\text { EDPYME Crear } \\
\text { Arequipa }\end{array}$ & RFI & Peru \\
\hline & & $\begin{array}{l}\text { Habitat Tacna } \\
\text { Siglo XXI }\end{array}$ & Habitat & $\begin{array}{l}\text { EDPYME Crear } \\
\text { Arequipa }\end{array}$ & RFI & Peru \\
\hline \multirow[t]{4}{*}{1999} & 7 & FEFAD & & ProCredit Bank & Bank & Albania \\
\hline & & $\begin{array}{l}\text { PRODEM (rural } \\
\text { portfolio) }\end{array}$ & & $\begin{array}{l}\text { PRODEM Fundo } \\
\text { Financiero Privado }\end{array}$ & FFP & Bolivia \\
\hline & & $\begin{array}{l}\text { IDEPRO, CIDRE, } \\
\text { FADES, and ANED }\end{array}$ & & $\begin{array}{l}\text { ECO Futuro Fundo } \\
\text { Financiero Privado }\end{array}$ & FFP & Bolivia \\
\hline & & K-Rep & World Education & $\begin{array}{l}\text { K-Rep Holdings (which } \\
\text { owns KRep Bank) }\end{array}$ & Commercial Bank & Kenya \\
\hline
\end{tabular}




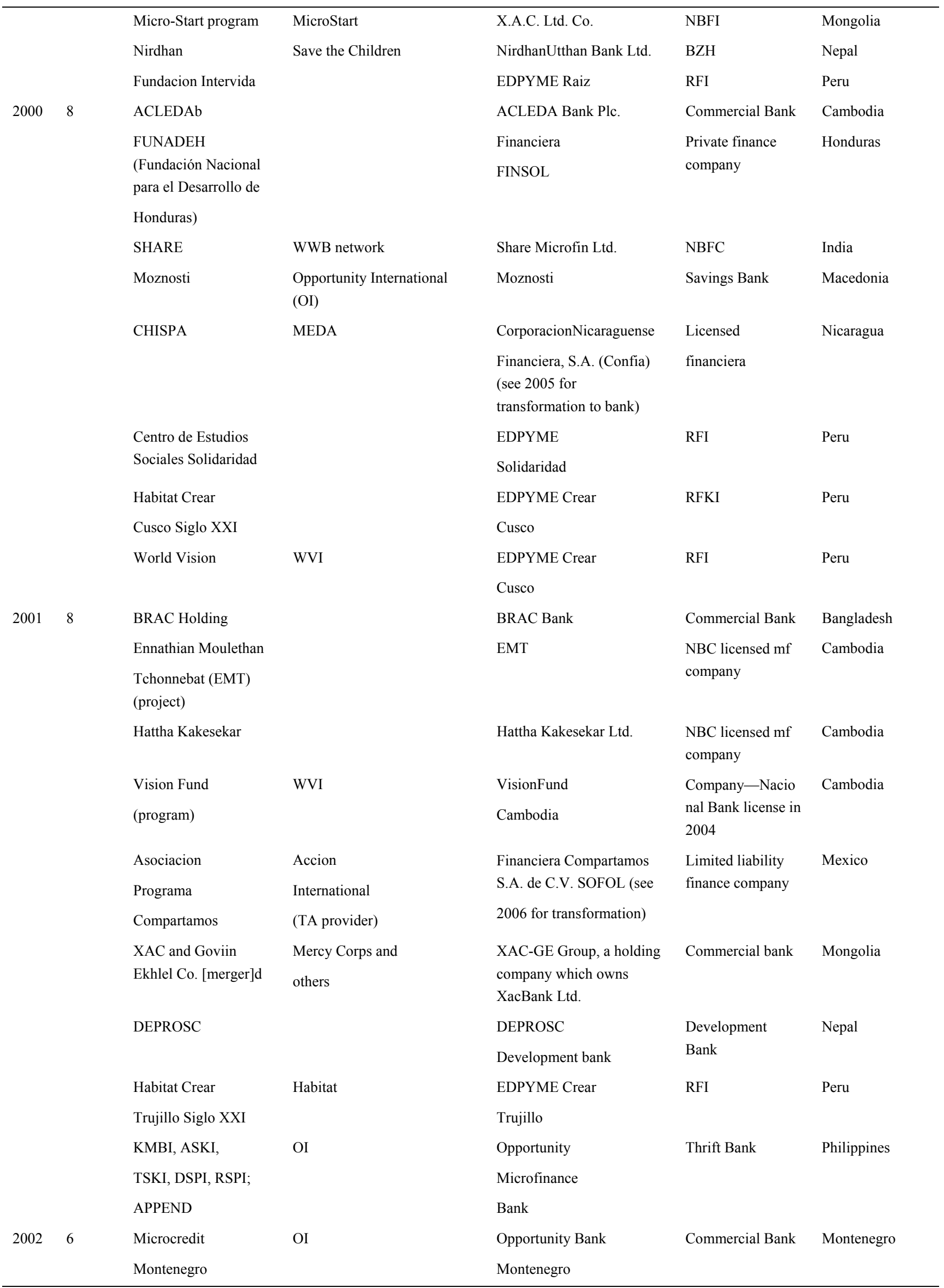




\begin{tabular}{|c|c|c|c|c|c|c|}
\hline & & Center for Self-Help & & Swalamaban & Development & Nepal \\
\hline & & Development (CSD) & & Nikas Bank (SBB) & Bank & \\
\hline & & Aga Khan Rural & Aga Khan & First Microfinance & Microfinance & Pakistan \\
\hline & & Support Program & & Bank & Bank & \\
\hline & & ARDCI & & Vision Bank & Rural Bank & Philippines \\
\hline & & E Zobel Foundation & & Banco Ng Masa & Rural Bank & Philippines \\
\hline & & (program) & & & & \\
\hline & & La Asociación del & & FINDESA & Deposit taking & Nicaragua \\
\hline & & Fondo del Instituto & & & NBFI & \\
\hline & & Nicaragüense de & & & & \\
\hline & & Desarrollo (FINDE) & & & & \\
\hline 2003 & 3 & ThaneakeaPhum & Catholic Relief & ThaneakeaPhum & Licensed & Cambodia \\
\hline & & (project) & Services (CRS) & Camdodia & $\begin{array}{l}\text { microfinance } \\
\text { company }\end{array}$ & \\
\hline & & FINCA Kyrgyzstan & FINCA & FINCA Microcredit & Microcredit & Kyrgyzstan \\
\hline & & (program) & International & Company & Company & \\
\hline & & ADOPEM & WWB network & Banco de Ahorro y Crédito & Saving and Loan & Nicaragua \\
\hline & & & & ADOPEM & bank & \\
\hline 2004 & 8 & CREDIT (project) & World Relief & CREDIT Microfinance & Kompani & Cambodia \\
\hline & & & & Institution & Mikrofinanciare e & \\
\hline & & & & & Licencuar $\mathrm{f}$ & \\
\hline & & FINCA Ecuador & FINCA & FINCA Ecuador & Regulated & Ecuador \\
\hline & & & International & & Financial & \\
\hline & & & & & Institution & \\
\hline & & Financiera Calpiag & IPC (TA provider) & Banco ProCredit & Bank & El Salvador \\
\hline & & Sinapi Aba Trust & OI & OI Sinapi Aba S\&L Ltd. & NBFI & Ghana \\
\hline & & FondasyonKole & & Sevis Finansye Fonkoze & NBFI & Haiti \\
\hline & & Zepol (Fonkoze) & & (Fonkoze Financial & & \\
\hline & & & & Services) & & \\
\hline & & Bullock Cart Workers' & & BWDA Finance & NBFC & India \\
\hline & & Development & & Limited (BFL) & & \\
\hline & & Association (BWDA) & & & & \\
\hline & & Programipër Financim & ADIE International (projekt) & Kreditimi Rural & LLC & Kosovo \\
\hline & & Rural & & iKosovës-KRK & & \\
\hline & & Ai-Ken, Ak-Peil & Mercy Corps & Kompanion & Microcredit & Kyrgyzstan \\
\hline & & Talas, Umai-Ene, & & Financial Group & Company & \\
\hline & & Keremet-Kol, Ak- & & & & \\
\hline & & MaalYug & & & & \\
\hline & & FINCA Uganda & FINCA & FINCA Uganda & Micro deposit & Uganda \\
\hline & & & & Ltd. & -taking & \\
\hline 2005 & 10 & Caja Los Andesh & IPC & Banco ProCredito & Commercial Bank & Bolivia \\
\hline & & Spandana & & Spandana & NBFI & India \\
\hline & & SKS & & SKS & NBFC & India \\
\hline & & Public Fund & Mercy Corps & Asian Credit & Newly formed & Kazakhstan \\
\hline & & Asian Credit Fund & & Fund LLP & Subsidiary & \\
\hline
\end{tabular}




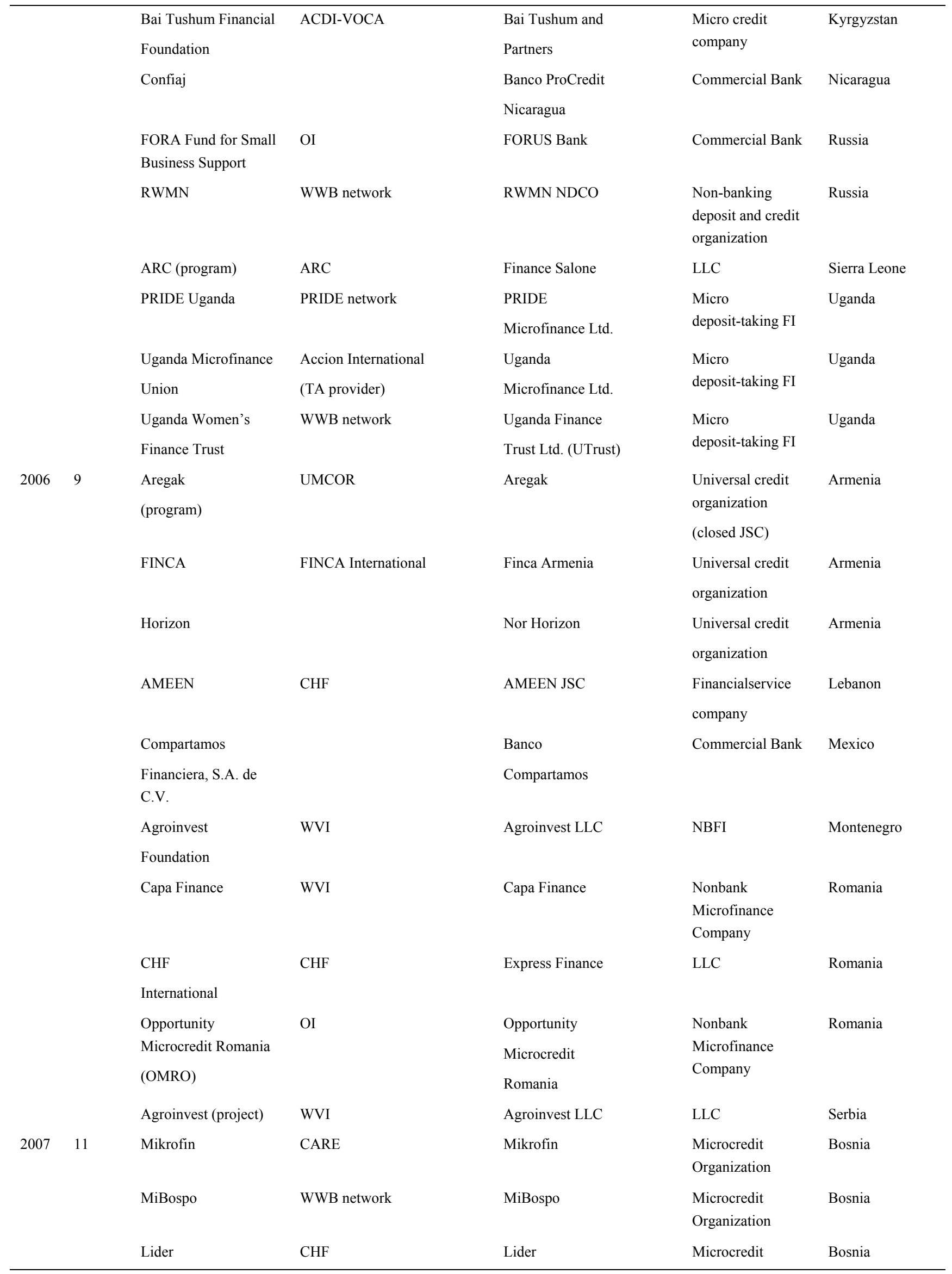




\begin{tabular}{|c|c|c|c|c|}
\hline & & & Organization & \\
\hline Constana & Save the Children & Constanta (JSC) & $\begin{array}{l}\text { Licensed } \\
\text { Microfinance } \\
\text { Organization }\end{array}$ & Georgia \\
\hline Crystal Fund & & Constanta (JSC) & $\begin{array}{l}\text { Licensed } \\
\text { Microfinance } \\
\text { Organization }\end{array}$ & Georgia \\
\hline $\begin{array}{l}\text { Small Business } \\
\text { Development } \\
\text { Fund }\end{array}$ & Oxfam GB & $\begin{array}{l}\text { Lazika Capital } \\
\text { (JSC) }\end{array}$ & $\begin{array}{l}\text { Licensed } \\
\text { Microfinance } \\
\text { Organizationlicenc } \\
\text { uar }\end{array}$ & Georgia \\
\hline $\begin{array}{l}\text { VisionFund } \\
\text { Credo } \\
\text { Foundation }\end{array}$ & WVI & Credo (LLC) & $\begin{array}{l}\text { Licensed } \\
\text { Microfinance } \\
\text { Organizationlicenc } \\
\text { uar }\end{array}$ & Georgia \\
\hline $\begin{array}{l}\text { Activists for Social } \\
\text { Alternatives- } \\
\text { GramaVidiyal } \\
\text { (ASA-GV) }\end{array}$ & & $\begin{array}{l}\text { GramaVidiyal } \\
\text { Microfinance Ltd }\end{array}$ & NBFC & India \\
\hline Bandhan & & Bandhan & NBFC & India \\
\hline $\begin{array}{l}\text { BSS (registered } \\
\text { public charity) }\end{array}$ & & BSS & NBFC & India \\
\hline $\begin{array}{l}\text { Kazakhstan Loan } \\
\text { Fund }\end{array}$ & ACDI-VOCA & Kaz Micro Finance & LLLC & Kazakhstan \\
\hline
\end{tabular}

Note. In some instances, the founding INGO may not have been involved with the NGO at the time of transformation. References to networks and TA providers include only those involved with the NGO at the time of transformation.

Source: Lauer, K., The Consultative Group to Assist the Poor-CGAP, 2008. "Transforming NGO MFIs: Critical Ownership Issues to Consider.

\section{Copyrights}

Copyright for this article is retained by the author(s), with first publication rights granted to the journal.

This is an open-access article distributed under the terms and conditions of the Creative Commons Attribution license (http://creativecommons.org/licenses/by/4.0/). 